\title{
Uzṇēmuma darbības turpināšanas audits un riska novērtējums
}

\author{
Jānis Mežiels ${ }^{1}$, Irina Voronova ${ }^{2},{ }^{1-2}$ Rīgas Tehniskā universitāte
}

\begin{abstract}
Kopsavilkums. Pētījums tiek saistīts ar 570. Starptautiskā revīzijas standarta: Uzṇēmuma darbības turpināšanas pienēmuma novērtēšana praksē. Tiek veikta auditoru atzinumu par darbības nepārtrauktību binomālo modeḷu faktoru analīze, integrālā novērtējuma metodolog̣iskie paņēmieni un risku klases atbilstība auditoru atzinumiem par darbības nepārtrauktību.

Autori, lai iegūtu darbības nepārtrauktības ievērošanas integrālo novērtējumu, ierosina izmantot hierarhijas analīzes metodi. Pētot sakarības starp bankrota prognozēšanas modeḷiem un darbības nepārtrauktības novērtējumu, tiek veikta divu nosacītās varbūtības modeḷu precizitātes pārbaude.
\end{abstract}

Atslēgas vārdi: Starptautiskie Revīzijas standarti, finanšu pārskatu revīija, pieṇēmums par uzṇēmuma darbības turpināšanu, bankrota prognozēšanas modeḷi.

\section{IEVADS}

Pēc Starptautiskajiem Revīzijas standartiem (SRS) ar pieņēmumu par uzṇēmuma darbības turpināšanu tiek uzskatīts, ka uzṇēmums pārredzamā nākotnē turpinās savu darbību [1]. Pēc 1. Starptautiskajā Grāmatvedības standartā (SGS) noteiktajām prasībām vadībai ir noteikts pienākums izvērtēt uzñēmuma spēju turpināt savu darbību. Savukārt revidents, veicot 315. SRS noteiktās risku izvērtēšanas procedūras, apsver, vai pastāv kādi notikumi vai apstākḷi, kuri var radīt nopietnas šaubas par uzṇēmuma spēju turpināt darbību. Darba mērķis ir izpētīt, kādus papildu instrumentus, novērtējot uzñēmuma darbības turpināšanas pienēemumu, var izmantot auditori. Autori analizē pazīmes, kuras izraisa šaubas par auditējamo uzṇēmumu spēju darboties tālāk, kā arī maksātnespējas stāvokḷa novērtēšanā izmantojamo diskriminantu analīzes modẹ̦u un riska indeksu pielietošanas iespējas.

CFA institūta biedru aptaujas laikā (CFA Institute Standards and Financial Market Integrity Division) $81 \%$ respondentu norādīja, ka Uzṇēmuma darbības turpināšanas pieņēmumam ir svarīga nozīme uzṇēmuma darbības analīzē. Bez tam $61 \%$ respondentu atzina, ka pasaules finanšu krīze ir iezīmējusi problēmas ar finanšu pārskatos ietveramās informācijas uzrādīšanu un atspogulošanu. Iepriekšminētajā CFA Institute aptaujā konstatēts, ka 81 procents aptaujāto uzskata, ka uzn̦ēmuma vadība ir atbildīga paziṇot ieguldītājiem, vai uzṇēmums turpinās darbosies arī turpmāk, kam seko neatkarīgais auditors (74 procenti) un uzñēmuma revīzijas komiteja (58 procenti). Aptaujas rezultāti liecina, ka zin̦ošana par uzñēmuma turpmāko darbību gulstas uz vairākām pusēm [2].

Savukārt Eiropas Komisijas Zaļajā grāmatā „Revīzijas politika - no krīzes gūtā pieredze'[3] norādīts, ka līdz šim revīzijas lielā mērā ir bijušas balstītas uz vēsturisko informāciju. Tiek norādīts, ka ir svarīgi apsvērt apmēru, kādā revidentiem būtu jānovērtē uzṇēmuma sniegtā informācija par nākotni, un, ņemot vērā to privileǵēto piekļuvi pamatinformācijai, - apmēru, kādā pašiem revidentiem būtu jānodrošina uzņēmuma saimnieciskā un finanšu prognoze. Pēdējais jo īpaši būtu piemērots „darbības turpināšanas” kontekstā. Daudzos uzņēmumos netiek veikta arī finanšu pārskatu rādītāju analīze, bet, ja tas notiek, galvenie aprēksinātie rādītāji ir likviditāte un rentabilitāte.

Tāpēc, veicot obligātās finanšu pārskatu revīzijas, par vienu no uzdevumiem varētu izvirzīt bankrota iespējamības diagnostiku. Tādējādi tiktu sasniegts Zaļajā grāmatā izvirzītais mērķis - tiktu veikta uz nākotni vērsta analīze, ieinteresētajām personām nodrošinot pievienoto vērtību, - kā arī reāli novērtēta uzṇēmuma darbības turpināšanas iespēja.

Darba mērksis ir izpētīt, kādus papildu instrumentus, novērtējot uzṇēmuma darbības turpināšanas pieṇēmumu, var izmantot auditori. Darba objekts ir darbības nepārtrauktības audits. Par pētījuma priekšmetu tiek izvirzīti darbības nepārtrauktības novērtēšanas metodoloǵiskie aspekti.

Izvirzìtā mērksa sasniegšanai tiek izmantotas šādas pētnieciskās izziņas metodes: monogrāfiskā metode, salīdzinošā analīze un sintēze, koeficientu veidošanas metode, tika veikta datu daudzfaktoru analīze. Aprēksini un datu apstrāde tika veikta, izmantojot MS Excel vidi.

Pirmajā darba daḷā autori apskata uzñēmuma darbības turpināšanas (going concern opinion) jēdziena vēsturisko attīstību, pēta uzṇēmuma darbības turpināšanas pieņēmuma novērtēšanas veidus, veic faktoru, kuri tiek izmantoti hipotēzēs, lai noteiktu to ietekmi uz uzñēmuma darbības turpināšanas pieñēmumu, faktogrāfisko analīzi, kā arī analizē pazìmes, kuras izraisa šaubas par auditējamo uzñēmumu spēju darboties tālāk. Lai samazinātu subjektīvisma pakāpes līmeni, slēdziena sagatavošanas laikā pieņēmuma par uzṇēmuma darbības turpināšanu novērtēšanai tiek piedāvāts izmantot trīs pakāpju algoritmu. Izmantojot hierarhijas analīzes metodi, tiek iegūts vispārīgs uzṇēmuma darbības turpināšanas pieṇēmuma atbilstības novērtējums, kuru atspoguḷo slēdzienā. Sakarā ar to, ka vispārīgais novērtējums ir saistîts ar bankrota vai maksātnespējas varbūtības noteikšanu, otrajā dal̦ā tiek novērtēts divu zinātnieku model̦u pielietojums Latvijas uzṇēmumiem. Katram modelim tiek aprēķinātas precizitātes pakāpes. 
$2013 / 24$

\section{UZN̦ĒMUMA DARBĪBAS TURPINĀŠANAS PIEN̦ĒMUMA IEVĒROŠANAS NOVĒRTĒŠANA}

Uz nākotni vērstu analīzi, vismaz lieliem biržas sarakstā iekl̦autiem uzṇēmumiem, līdz šim ir veikuši akciju analītiķi un kredītreitinga aǵentūras, bet revidentu potenciāls šajā virzienā nav ticis izmantots. Tomēr atzīmēsim, ka, veicot revīzijas procedūras, mērksis ir:

- iegūt pietiekamus un atbilstīgus revīzijas pierādījumus, kas apliecina vadības pieņēmuma par uzņēmuma darbības turpināšanu atbilstību, kurš izmantots, sagatavojot finanšu pārskatus;

- balstoties uz iegūtajiem revīzijas pierādījumiem, izdarīt secinājumus par to, vai pastāv ar tādiem notikumiem vai apstākḷiem saistītas būtiskas nenoteiktības, kuras var radīt nozīmīgas šaubas par uzṇēmuma spēju turpināt darbību;

- noteikt, kā tas ietekmēs revidenta ziņojumu.

\section{A. Uzņēmuma darbības turpināšanas (going concern} opinion) jēdziena attīstības apskats

Uzṇēmuma darbības turpināšanas jēdziena attīstību jāapskata saistībā ar atsevišksām grāmatvedības uzskaites sistēmām - Britu-amerikāṇu skolu, kontinentālo un musulmaņu. Plašu empīirisku grāmatvedības uzskaites teorijas attīstības pētījumu veicis Al-Adeem, K.R. [4]. Tā ietvaros atzīmēts, ka pēc Belkaouir [5] datiem grāmatvedības uzskaites teorijas struktūru sastāda četri uzskaites pienēmumi, teorētiskā koncepcija un grāmatvedības uzskaites principi. Starp pieņēmumiem būtisku vietu ieņem - pieņēmums par uzṇēmuma darbības turpināšanos.

Visvairāk publicēto pētījumu par biznesa nepārtrauktības koncepciju ir kontekstā ar Britu-amerikāņu skolu. Samērā detalizēti šīs koncepcijas jēdziena attīstību saistībā ar Brituamerikāņu skolu, izmantojot arī R. K. Storey [6] un C.T. Devine darbus, izklāstījis W. Hahn [7]. Viņa darbā apkopota iepriekšminētās koncepcijas jēdziena hronoloǵiskā attīstība no 1620.gada līdz 2011.gadam. Pētnieki atzīmē, ka biznesa nepārtrauktības koncepcijas rašanās 1620.gadā ir tiesiski pamatota. Tiesas procesa laikā tiesa konstatēja, ka sakarā ar darbības nepārtrauktību uzṇēmuma vērtība būs augstāka nekā bilances vērtība, jo uzṇēmumu uz nākotnes operāciju rēķina var izmantot virspel̦

Tiek atzīmēts arī Berlīnes advokāta G.V. Simona veikums, kurš, pamatojoties uz vispārējo tirdzniecības kodeksu, 1861.gadā publicēja monogrāfiju par bilances likumiem un kura tiek atzīta par statistisko bilanču teorijas pamatdokumentu. Simons savos spriedumos vadās no uzṇēmējdarb̄̄ibas turpināšanas principa, kuru tajā laikā sauca par „turpināšanās statistiku” (A. Moksters). Saskaņā ar Simona statistikas turpināšanās koncepciju saimnieciskās darbības subjekta īpašums un saistības bilancē tiek atspogulıotas un novērtētas noteiktā datumā, ņemot vērā paredzamo organizācijas saimnieciskās darbības nepārtrauktîbu [8, 10.lpp.]. Tādā veidā darbības nepārtrauktības pieņēmuma principa sākotnējais attīstības etaps gan britu-amerikāņu, gan kontinentālajā sistēmā aizsākās tiesiskajā vidē.
Pēc Storey [6] datiem pirmais, kurš deva darbības turpināšanas pieñēmuma aprakstu un pamatojumu, 1892.gadā bija L.R. Dicksee. Savukārt 1909.gadā H.R. Hatfield publicētajā darbā "Mūsdienu audits: praktiskā rokasgrāmata auditoriem" organizēja darbības nepārtrauktības pieņēmuma apspriešanu, bet 1927.gadā viņš rakstā "Grāmatvedības uzskaite: principi un atsevišksas problēmas" darbības nepārtrauktību pieņēmumu jau ir noteicis kā vispārpieņemtu principu [7].

Vācijā darbības nepārtrauktības princips pirmo reizi oficiāli tika atspogulıots 1985.gada Tirdzniecības kodeksa 252.§ kā viens no galvenajiem uzskaites principiem: „Novērtēšana jāveic, pamatojoties uz organizācijas saimnieciskās darbības nepārtrauktību, ja vien tas nav pretrunā ar faktiskajiem vai tiesiskajiem apstākḷiem” [9, 57. lpp.].

Tālākā darbības nepārtrauktības pieñēmuma attīstība, sākot no 1953.gada, ir cieši saistīta ar Amerikas profesionālo asociāciju un institūtu izstrādnēm [6]. Savukārt 2011.gadā Finanšu grāmatvedības standartu padome (FGSP) (Financial Accounting Standards Board (FASB)) plānoja pieņemt Uzñēmuma darbības turpināšanas standarta projektu, tomēr 2012.gada aprīli FGSP pretēji priekšlikumam nolēma nepieprasīt papildus kvalitatīvās prasības informācijas atklāšanai saistībā ar darbības nepārtrauktību. Kā standarta neapstiprināšanas galvenais iemesls tika minēta nevēlēšanās darboties bez pārējo ieinteresēto profesionālo organizāciju atbalsta.

Tieši tagad neatkarīgajam auditoram ir nepieciešams (pēc revīziju, ne grāmatvedības standartiem) atklāt tās revidentu ziņojumā, ja pastāv būtiskas šaubas par uzṇēmuma spēju turpināt darboties arī turpmāk. Tā ir revidenta atbildība, nevis vadības atbildība, veikt darbības turpināšanas novērtējumu. Pamatojoties uz paveikto darbības nepārtrauktības pieņēmuma jēdziena attīstības apskatu, autori konstatēja, ka grāmatvedības uzskaitē organizācijas darbības nepārtrauktība tiek definēta samērā precīzi, savukārt auditā pilnīgāk, bet ar iespējamības novērtējumu.

Neraugoties uz praktiski vienoto grāmatvedības uzskaites un audita mērķi, darbības nepārtrauktības pieņēmumi atšķiras. Grāmatvedības uzskaitē, pamatojoties uz grāmatvedības uzskaiti regulējošajiem likumdošanas normatīvajiem aktiem un līgumiem, nepieciešams novērtēt organizācijas plānus saistībā ar savas darbības turpināšanu. Auditā, pamatojoties uz organizācijas vadības veiktajām darbībām, kā arī citiem ārējiem faktoriem, jānovērtē vesela faktoru kopa, kura ietekmē darbības nepārtrauktību un organizācijas uzbūves modeli tuvākajā perspektīvā. Tieši š̄ iemesla dēl darbības nepārtrauktības novērtēšana audita un grāmatvedības uzskaites vajadzībām kḷūst atšķirīga.

Darbības nepārtrauktība tiek apskatīta arī no risku novērtēšanas viedokḷa un to ietekmes uz organizācijas darbību. Tādos gadījumos tiek pētītas ārkārtas apstākḷlos vai pēc katastrofām pielietotās vadības metodes. (Business Continuity Planning - BCP). Šis virziens atspogulots J. Graham un D. Kaye [10], A. Hiles [11], Syed Akhtar un Afsar Syed [12], V.V. Drožžinovs un Moiseenko [13] darbos. 


\section{B. Darbības nepārtrauktības pieñēmuma ievērošanas} novētējums

Autori, pētot darbības nepārtrauktības pieṇēmuma ievērošanas novērtēšanu problēmas, veica šim mērksim izmantojamo metožu apskatu. Pētījums aptvēra plašu valstu loku - ASV, Kanādu, Japānu, Malaiziju, Taivānu, Irānu, Nīderlandi, Vāciju un citas. Analīzes rezultāti l̦āva izdarīt secinājumu, ka eksistē divi šādu pētījumu virzieni. Pirmais virziens saistīts ar kopsakarību atklāšanu starp auditora slēdziena par darbības nepārtrauktību pirms bankrota iestāšanās un dažādiem faktoriem. Kā likums, šis virziens tiek bāzēts uz biržā kotēto uzņēmumu audita rezultātiem. Pie šì pētijuma virziena var pieskaitīt Abota. L (Abbott L. at el), [14], Geigera M.A. (Geiger M.A.) un Rama.D.V. (Rama D.V.)[15], Kaplana S.E. (Kaplan S.E.) un Viljamsa D.D (Williams D.D.) [16], Vanstreilena A. (Vanstraelen A.) [17], Forodži D.(Foroghi, D.), Šahāhani A.M.(Shahhahani, A.M.) [18] un citu pētījumus. Faktoru ietekmes noteikšanai tiek izmantota bināri loǵiskā regresijas metode, kuru 1944.gadā izstrādāja Berksons (Berkson) [19]. Pirmais, kurš pirmo reizi to izmantoja finansiālo grūtību novērtēšanai, 1980.gadā bija Olsons (Ohlson) [20]. ${ }^{1}$ Vienādojumā iekḷauto faktoru skaits svārstās no 5 līdz 19 un tos var apvienot trīs grupās (sk.1.tabulā) - finanšu (1.), korporatīvās pārvaldības (2.) un citi ( piemēram, auditorkompāniju raksturojošie) (3.) rādītāji.

Otrs virziens pamatojas uz darbības nepārtrauktības novērtēšanai izmantojamo metožu izpēti un kompleksu auditora slēdziena novērtējuma formēšanu. Šis virziens vairāk tiek pielietots Krievijā un parasti nebāzējas uz biržā kotēto uzñēmumu datiem, bet tiek apskatīts no auditoru viedokḷa, lai uzlabotu vinu darbu.

Autori 1.tabulā apkopoja vienādojumā ietvertos faktorus, kuri ļauj noteikt saistību starp auditoru slēdzienu par darbības nepārtrauktību pirms bankrota. Konkrētie model̦i autoriem l̦auj izpētīt dažādas hipotēzes par saistību starp auditoru slēdzieniem par darbības nepārtrauktību un dažādiem faktoriem, piemēram, auditorkompānijas lielumu, audita izmaksām utt. 1.tabulā atspoguḷotie model̦i izstrādāti, izmantojot biržā kotēto uzñēmumu datus.

Analogiski faktogrāfiski pētījumi, kuri būtu veikti biržā nekotētiem uzñēmumiem, autoriem nav zināmi.

Viens no faktoriem, kurš ietilpst model̦u finanšu rādītāju grupā, ir bankrota iespējamības skaitliskais novērtējums (arī finanšu stresa novērtējums). Lai novērtētu bankrota iespējamību, pētnieki izmantoja Zmijevska modeli (1984) [21], Hopvuda modeli (Hopwood model) [22] vai arī pašmāju model̦us. Piemēram, Foroghi D., Shahhahani A.M [18], pētot auditoru slēdzienu pirms bankrota, izmantoja 54 Teherānas biržā reǵistrētus uzñēmumus un pēc nacionālā model̦a veica bankrota iespējamības aprēķinus.

No 12 piedāvātajiem pētījumiem (sk.1.tabulu) izmantoti 7 bankrota iespējamības model̦i, kurus var attiecināt uz probit/logit model̦u tipa grupu.

1 Autori neapspriež jēdziena „finansiālās grūtības” (financial distress) attīstību, bet izmanto to kā paziṇojumu par bankrotu/maksātnespēju Altmana (1968), Olsona (1980) un Zmijevska (1984) interpretācijā
1. TABULA

AUDITORU SLĒDZIENU BINOMĀLO MODEL̨U PAR DARBĪBAS NEPĀRTRAUKTĪBU RAKSTUROJUMS

\begin{tabular}{|c|c|c|c|c|c|c|}
\hline \multirow[t]{4}{*}{ Model̦u autori } & \multirow{4}{*}{ 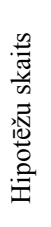 } & \multicolumn{5}{|c|}{ Faktoru raksturojums modelī } \\
\hline & & \multirow{3}{*}{ 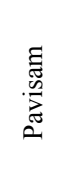 } & \multicolumn{4}{|c|}{ Grupa } \\
\hline & & & 1. & $\frac{\dot{\varphi}}{\dot{m}}$ & 2. & 3. \\
\hline & & & & $(1)^{*}$ & & \\
\hline $\begin{array}{l}\text { 1.Belloty X., Uang J-J., Citron } \\
\text { D., Taffler R. }\end{array}$ & & 13 & 10 & + & 1 & 2 \\
\hline $\begin{array}{l}\text { 2. Lawrence J.A., Parker S., } \\
\text { Peters G. F. }\end{array}$ & & 13 & 9 & - & 0 & 4 \\
\hline 3. Geiger M.A., Rama D.V. & 3 & 5 & 3 & + & 1 & 1 \\
\hline $\begin{array}{l}\text { 4. Jiang, L., Radich, R., Zhao, S } \\
\text { (USA un Australija) }\end{array}$ & 2 & 10 & 9 & - & 0 & 1 \\
\hline 5. Kaplan S.E., Williams D.D. & 4 & $5-8$ & 3 & + & 1 & $1 / 4$ \\
\hline $\begin{array}{l}\text { 6. Foroghi, D., Shahshahani, A. } \\
\text { M. (Irans) }\end{array}$ & & 7 & 4 & + & 2 & 1 \\
\hline 7. Vanstraelen, A.( Belgium) & 2 & 11 & 7 & + & 3 & 1 \\
\hline $\begin{array}{l}\text { 8. DeFond M.L., Francis J.R, Hu } \\
\text { X. (USA) }\end{array}$ & 1 & 19 & 8 & + & 1 & 10 \\
\hline $\begin{array}{l}\text { 9. Trønnes P.C., Carson E., Simnett } \\
\text { R. (USA, UK, Australija) }\end{array}$ & 3 & 16 & 9 & + & 4 & 2 \\
\hline 10. Ratzinger N. (Vacija) & 2 & 14 & 1 & - & 1 & 12 \\
\hline $\begin{array}{l}\text { 11. Sormunen N., Jeppesen K.K., } \\
\text { Sungren S. Svanströn T. }\end{array}$ & 1 & 10 & 5 & - & 0 & 5 \\
\hline $\begin{array}{l}\text { 12. Basioudis I.G., Geiger M.A. } \\
\text { Papanastasiou V. (UK) }\end{array}$ & 2 & 11 & 7 & + & 0 & 4 \\
\hline \multicolumn{6}{|c|}{$\begin{array}{l}\text { (1) - finansiālo grūtību vai bankrota iespējamības raksturojošie rādītāji; } \\
\text { '+' - novērtējums iekḷauts; '-' - nav iekḷauts. }\end{array}$} & \\
\hline
\end{tabular}

Pēc Ovčiņņikovas N.N. [38] uzskatiem, Krievijā izmantojamās pieejas, lai novērtētu darbības nepārtrauktības principu, var iedalīt divās grupās. Tā, piemēram, Remizova M.А. (Ремизов М.А.) [39] metodika ir samērā ierobežota, jo tajā nav iekḷauta finansiālā stāvokḷa analīze, prognozējamās finanšu informācijas novērtējums tiek ierobežots tikai ar plānu apspriešanu un netiek balstīts uz faktogrāfiskiem aprēķiniem.

Kā tipiskākais otrās grupas pārstāvis ir Meḷnika M.V.

(Мельник М.В.) metodika, kurā ieklauts liels skaits rādītāju, nosacījumu un kuru noskaidrošana ierobežotas informācijas apstākļos ne vienmēr ir iespējama.

Ovčiņnikova N.N (Овчинникова Н. Н.) [40], balstoties uz Krievijas Auditoru ziņojumu sastādīšanas noteikumiem Nr.11 [41], kā arī izmantojot Šalanova N.V. (Шаланов Н. В.) [42] sistēmanalīzes analītiskās metodes, lai novērtētu organizācijas darbības nepārtrauktību, piedāvāja izmantot rādītāju kompleksa integrālo novērtējumu, kurā piedāvātas 6 iespējamās darbības nepārtrauktības neatbilstības pazīmju grupas. Pēc autoru domām, lai pielietotu Šalanova N.V. 
$2013 / 24$

metodi, kuras pamatā ir potenciāla teorija, nepieciešams paskaidrojums par katras grupas rādītāja robežvērtībām.

Veicot dažādu nozaru uzṇēmumu auditu, šo rādītāju noteikšana ir saistīta gan ar informācijas, gan ar laika deficīta problēmām.

Autori pozitīvi vērtē Ovčiņņikovas N.N [40] piedāvāto integrālā novērtējuma metodisko pieeju, jo tā izmantojama dažādu lielumu uzṇēmumiem. Tomēr šai pieejai ir šaurs pielietojums, jo tas izstrādāts kooperatīvo organizāciju darbības nepārtrauktības novērtējumam.

Uzņēmumu parasti novērtē, ņemot vērā darbības turpināšanas pieņēmumu, tas nozīmēe, ka tas tuvākajā nākotnē turpinās darbību. Šis pien̦ēmums nozīmē to, ka nepastāv nodomi likvidēt vai būtiski samazināt uzņēmuma darbības apjomus. Ja eksistē pretēji plāni, tad šis pamatojums ir jāatspoguḷo finanšu pārskatos, kuru sastādīšanai tiek pielietoti citi principi. Faktiski sastādot finanšu pārskatus, uzṇēmuma vadībai obligāti jāpamato darbības nepārtrauktības pieņēmuma atbilstību. Pieñēmums īpaši svarīgs, novērtējot aktīvus, kurus uzṇēmumā tuvākajā nākotnē paredzēts izmantot.

Autori pieñēmuma par uzṇēmuma darbības turpināšanu novērtēšanai piedāvā izmantot trīs līmeņu algoritmu. Pirmajā līmen̄i, balstoties uz uzñēmuma vadības un vadošo speciālistu domām par uzṇēmuma spēju turpināt darbību, tiek novērtēti faktori un informācija, kura var radīt nopietnas šaubas par uzṇēmuma spēju turpināt darbību. Otrajā līmen̄i, izmantojot analītiskās procedūras, t.sk. bankrota prognozēšanas modeḷus, tiek novērtētas slēptās uzṇēmumu finansiāli ekonomiskā stāvokḷa pazīmes un to ietekme uz spēju nodrošināt darbības nepārtrauktību. Novērtējuma finanšu rādītāju grupā autori piedāvā iekḷaut bankrota varbūtības aprēķinu, kurš pamatojas vismaz uz viena vai divu no trīs modelı klasēm izmantošanu (diskriminatu, logit/ probit un riska). Autori bankrota varbūtības novērtēšanas rezultātu piedāvā noteikt kā vidēji svērto vērtību no visiem rādītājiem. Rādītāju skaits grupā nedrīkst pārsniegt 10. Trešajā līmen̄̄, izmantojot hierarhijas analīzes metodi (analytic hierarchy process - AHP), tiek veikts apkopojošais uzņēmuma darbības turpināšanas pieñēmuma ievērošanas novērtējums, un tiek gatavots slēdziens par iepriekšminētā principa atbilstību.

Darbības nepārtrauktības pieñēmuma ievērošanas novērtēšanai izmantotā hierarhijas analīzes metode dos iespēju izsvērt katra rādītāja ietekmi uz gala slēdzienu.

III. BANKROTA IESPĒJAMĪBAS PROGNOZĒĔSNAN MODEḶU UN UZN়ĒMUMA DARBĪBAS TURPINĀŠANAS PIEN̦ĒMUMA SAIKNE

\section{A. Darbības nepārtrauktības novērtēěanas un bankrota prognozēšanas modeļu saistības pētījumi}

Bankrota prognozēšanas model̦us auditori var izmantot, lai palīdzētu tiem noformēt savu subjektīvo viedokli par darbības nepārtrauktības novērtējumu. Piedāvātos model̦us auditori var izmantot audita sākumposma risku novērtēšanai, nepieciešamo audita procedūru noteikšanai. Tāpat tos var izmantot arī kā analītisko instrumentu sarunām par klienta problēmām, izstrādātu rekomendācijas finanšu pārskatu izmaiņām, vai arī samazinātu pret sevi vērstos tiesvedību riskus. Lai gan auditoriem ir liela pieredze attiecībā uz darbības nepārtrauktības pieñēmumu un tiem ir labas zināšanas par situāciju uzṇēmumos, bieži vien līdz pat klienta bankrotam par šī principa neatbilstību iebildes netiek dotas. Tādus gadījumus pētījis Lili S. [43] Pētnieks analizē saikni starp bankrota stresa līmeni, auditējamā klienta lielumu, nosakot četru bankrota prognozēšanas model̦u precizitāti: attiecīibā uz auditoru iebildēm par darbības nepārtrauktību; Altmana Z-kritēriju, Zmijevska bankrota varbūtību un akciju ienesīgumu. Pētījuma rezultāti parādīja, ka Zmijevska modẹ̦a un akciju ienesīguma rādītāja precizitāte ir augstāka nekā divi pārējie model̦i.

Antonijs Jangs (Antony Young) un Ji Vangs (Yi Wang) [44], pamatojoties uz literatūras apskatu, parādīja, ka auditori darbības nepārtrauktības riska novērtējumu, kā likums, apskata kā viendabīgas klases risku. Tas notiek, neskatoties uz to, ka auditoriem ir tiesības dot dažādas iebildes attiecībā uz darbības nepārtrauktību. Atšķirībā no iepriekšējiem pētījumiem, kuri bāzējās uz binominālajiem model̦iem (sk. 2.tabulu), Antonijs Jangs un Ji Vangs piedāvāja piecu risku klases. Katra no tām saistīta ar iebildēm par darbības nepārtrauktību.

Risku klases autori noteica, izmantojot Altmana Z kritēriju (Altman Z-score.). Pētījuma rezultāti, kuri iegūti, izpētot Altmana Z kritērija un auditoru slēdzienu saikni par 63 celtniecības nozares uzñēmumiem laika periodā no 1989.gada līdz 2007.gadam, apkopoti 2.tabulā.

\section{B. Maksātnespējas novērtēšanas modeļu attīstības apskats: Latvijas pieredze}

Lai attīstītu bankrota varbūtības prognozēšanas modeḷus, 60. gadu beigās un 70. gadu sākumā tika izmantota daudzdimensiju diskriminantu analīze (MDA). Izmantojot diskriminantu analīzi, tika izstrādāti divi paz̄stami Altmana (1968) un ZETA (Altman, 1977) bankrota prognozēšanas model̦i. Sākot no 80. gadu sākuma bankrota prognozēšanai sāka izmantot vairāk attīstītas metodes, tādas kā probit un logit (Zmijevskis, 1984). Ārvalstu zinātnieki bankrota prognozēšanas metodes un model̦us izstrādājuši pēc finanšu pārskata informācijas, kas sagatavota saskaṇā ar savas valsts nacionālajiem grāmatvedību reglamentējošiem normatīvajiem aktiem un uzskaites standartiem, līdz ar to kritiski jāvērtē šo prognozēšanas metožu tieša lietošana Latvijas uzņēmumu finanšu pārskatu analīzē.

Praktisku interesi izraisa pētījumi, kuri pārbauda ārzemju bankrota prognozēšanas modeḷu izmantošanas iespējas Latvijas apstākḷlos. Pētījumus veikuši tādi autori kā R. Šorins un I. Voronova, J. Romancēviča un I.Voronova (2000), R. Šneidere (2009.), I. Genriha un I. Voronova (2010.), D. Šksiltere un R. Žuka (2010.), K. Didenko, J. Mežiels un I. Voronova (2012.) [45, 46, 47, 48, 49, 50].

Lielākā daḷa model̦u, kuri pētīti iepriekšminētajos darbos, ir pieskaitāmi diskriminantu analīzes un riska indeksa model̦iem. İss, bankrota/maksātnespējas riska novērtēšanai izmantojamo model̦u apskats, kuri piemērojami ne tikai Latvijas uzn̄ēmumiem, bet ar̄i izmantojami Igaunijas un Lietuvas apstākḷos, tika sniegts I. Voronovas darbā [ 51].

Latvijas apstākḷiem piemērotus modeḷus izstrādājuši R. Šorins un I. Voronova (1998), Z. Muceniece un N. Lāce. (2011), I. Genriha, G. Pettere un I. Voronova (2011) [45, 52, 53]. 
2.TABULA

RISKU KLASES UN AUDITORU SLĒDZIENU ATBILSTĪBA [autoru izstrādāta tabula, izmantojot [ 44 , 756. - 760.lpp.]]

\begin{tabular}{|c|c|c|}
\hline \multirow{2}{*}{$\begin{array}{l}\text { Altman } \\
\text { Z-score }\end{array}$} & \multicolumn{2}{|c|}{ Revidenta atzinumi saskaņā uz riska klasēm } \\
\hline & $\begin{array}{l}\text { Riska klase un tās } \\
\text { raksturojums }\end{array}$ & $\begin{array}{l}\text { Raksturojums saskaņā ar Austrālijas } \\
\text { Audita un apdrošināšanas standartiem } \\
\text { (2006.g.,jūlijs) }\end{array}$ \\
\hline \multirow[t]{2}{*}{$3,075<\mathrm{X}$} & $\begin{array}{l}\text { 1. klase. } \\
\text { Zems risks }\end{array}$ & $\begin{array}{l}\text { Atzinums bez iebildēm (t.sk nav norādīti } \\
\text { apstākḷu akcentējumi), jo "sākotnējā } \\
\text { riska novērtējums" ir "zems", }\end{array}$ \\
\hline & $\begin{array}{l}\text { 2. klase } \\
\text { Pamatotas cerības } \\
\text { uz } \\
\text { nepārtrauktību }\end{array}$ & $\begin{array}{l}\text { Atzinums bez iebildēm (t.sk nav norādīti } \\
\text { apstākḷu akcentējumi), jo ,sākotnējā } \\
\text { riska novērtējums", nav "zems", bet ir } \\
\text { "mazināšanas apstākḷi", kas atḷauj dot } \\
\text { atzinumu bez piezīmēm }\end{array}$ \\
\hline $\begin{array}{c}2,475<\mathrm{X} \\
<3,075\end{array}$ & $\begin{array}{l}\text { 3. klase } \\
\text { Iespējama } \\
\text { nepārtraukta } \\
\text { darbība }\end{array}$ & $\begin{array}{l}\text { Uzsvars, pamatojoties uz to, ka "maz } \\
\text { ticams', vai uzņēmums turpinās } \\
\text { darboties arī turpmāk", un tur ir } \\
\text { atbilstoša atklāšana. } \\
\text { "Izņemot" lēmumu, ja nav "pamatotas } \\
\text { cerības, ka uzn̄ēmums turpinās darboties } \\
\text { arī turpmāk", bet revidents nav } \\
\text { pārliecinājies, vai "maz ticams, ka } \\
\text { uzṇēmums turpinās darboties arī } \\
\text { turpmāk". Tomēr ir nepietiekama } \\
\text { atklāšana. } \\
\text { Negatīvais atzinums pamatojas uz faktu, } \\
\text { ka revidentam nav pierādījumu vai "maz } \\
\text { ticams, ka uzñēmums turpinās darboties } \\
\text { arī turpmāk", bet ir pietiekami, ja "trūkst } \\
\text { informācijas, lai garantētu negatīvu } \\
\text { atzinumu". } \\
\text { Akcentēts atzinums, kurā revidents nav } \\
\text { pārliecinājies, ka "maz ticams, vai } \\
\text { uzñēmums turpinās darboties arī } \\
\text { turpmāk", un tur ir nepietiekama } \\
\text { atklāšana, ciktāl viedoklis ir } \\
\text { attaisnojams. }\end{array}$ \\
\hline $\begin{array}{l}1,875<X \\
<2,475\end{array}$ & $\begin{array}{l}\text { 4. klase. } \\
\text { Pilnībā } \\
\text { iespējama } \\
\text { nepārtraukta } \\
\text { darbība, bet ir } \\
\text { pamatota } \\
\text { nenoteiktība }\end{array}$ & $\begin{array}{l}\text { Atteikums. Auditors nav apmierināts ar } \\
\text { to, ka tuvākajā nākotnē uzṇēmuma } \\
\text { darbība pilnīgi iespējama, bet } \\
\text { nenoteiktība garantē viedokḷa izpaušanas } \\
\text { atteikumu. }\end{array}$ \\
\hline $\mathrm{X}<1,875$ & $\begin{array}{l}\text { 5. klase } \\
\text { Darbības } \\
\text { turpināšanās ir maz } \\
\text { ticama }\end{array}$ & $\begin{array}{l}\text { Negatīvs atzinums. Auditors uzskata, ka } \\
\text { uzņēmuma darbība tuvākajā nākotnē ir } \\
\text { maz ticama. }\end{array}$ \\
\hline
\end{tabular}

M. Zmijevska modelī ir ieklauts reitinga koeficients, kuru nosaka, pamatojoties uz trīs finanšu rādītājiem, un tā aprēķinā formula ir šāda:

$X=-4,336-4,513 \cdot X_{1}+5,679 \cdot X_{2}-0,004 \cdot X_{3}$,

$$
P B=1 /(1+\exp (-X))
$$

kur $P B$ - bankrota varbūtība;

$X_{1}$ - neto pel̦na/ aktīvi;

$X_{2}$ - saistības/ aktīvi;

$X_{3}$ - apgrozāmie līdzekḷi/ īstermiņa saistības.

Reitinga koeficients (X) tiek izmantots, lai, pamatojoties uz normālo standarta sadalījuma funkciju (probit-regresiju), noteiktu bankrota varbūtību. Šo varbūtības vērtību, izmantojot NORMSDIST funkciju, var viegli aprēksināt MS Excel vidē. Ja iegūtā varbūtība ir lielāka vai vienāda ar 0,5 , tad rezultāts tiek klasificēts kā iespējamais bankrota stāvoklis, ja tas ir mazāks par 0,5 , tad bankrota varbūtība ir zema.

Pēc R.Šneideres veiktajiem model̦a testiem, kuri iegūti, izmantojot 232 Latvijas uzṇēmumu finanšu pārskatus [47, 186.lpp.], tā precizitāte pirmās grupas uzṇēmumiem (maksātnespējīgie) bija $76.7 \%$, bet otrai grupai (maksātspējīgie) - 85.5\% (autoru aprēksināts pēc [47, 190.lpp.]).

Šos rezultātus autori nevar uzskatīt par pietiekami ticamiem, jo R. Šneidere nav sniegusi paskaidrojumu, ka reitinga koeficients tiek izmantots, lai noteiktu varbūtỉbu, bet nav meklējamā vērtība [47, 136. lpp.]. Pēc I. Genrihas un I. Voronovas datiem [54], M. Zmijevska modela precizitāte sastāda 60,31\% un AUROC (AUROC ratio/Area) - 64,33\%. Pēc š̄ pētìjuma datiem modeḷa precizitāte tiek vērtēta kā vidēja [54].

I. Genrihas, G. Petteres un I. Voronovas [53] darbā tiek piedāvāts trīs faktoru modelis, kuršs, izmantojot bināri loǵistisko regresijas palīdzību un pamatojoties uz 1272 Latvijas uzņēmumu vēsturiskajiem datiem, l̦auj noteikt to maksātnespējas varbūtību:

$$
\begin{gathered}
Z=25,998 X_{1}+33,358 X_{2}+16,208 X_{3}-5.662, \\
P D=\frac{1}{\left(1+e^{-Z}\right)},
\end{gathered}
$$

kur $P D$ - saistību nepildīšanas varbūtība viena gada laikā; $X_{1}$ - standartizēta un transformēta rādītāja vērtība, pel̦na pirms nodokḷiem /pašu kapitāls ( $\left.K_{1}\right)$; $X_{2}$ - standartizēta un transformēta rādītāja vērtība, neto apgrozījums/aktīvi $\left(K_{2}\right)$;

$X_{3}$ - standartizēta un transformēta rādītāja vērtība, ilgtermina saistības /aktīvi $\left(K_{3}\right)$.

Rādītāju standartizācijas piemērs atspoguḷots I. Genrihas, G. Petteres un I. Voronovas darbā [54].

Piedāvātais modelis dod iespēju maksātnespēju novērtēt ar $72,3 \%$ varbūtību. Autori, ņemot vērā, ka auditori, pētot darbības nepārtrauktības radīto iebildumu sakarības, visbiežāk izmanto model̦us, kuri ietilpst nosacītās varbūtības grupā, veica 2 probit model̦u precizitātes pārbaudi.

\section{B. Bankrota modeļu precizitātes novērtējuma izpēte}

M. Zmijevska, I. Genrihas, G. Petteres un I. Voronovas modelıu precizitātes pārbaude tiek veikta, pamatojoties uz 48 Latvijas mazo un vidējo uzņēmumu datiem laika periodā no 2008. līdz 2011.gadam. Autori izpētîja 48 uzņēmumus, tomēer jāatzīmē, ka katrā no periodiem dažādu faktoru dēl (bankrots vai datu trūkums) to skaits mainījās. Rādītāju noteikšanas, iegūto rezultātu un to novērtējuma piemērs tiek sniegts 3.tabulā. Apkopojot noteiktos bankrota varbūtības rezultātus par laika periodu no 2010. līdz 2011.gadam (sk.2.att.), autori konstatēja, ka pēc M.Zmijevska modeḷa lielākā daḷa 
3. TABULA

UZN̦ĒMUMU BANKROTA RISKA VARBŪTĪBAS APRĒĶINA REZULTĀTI ( FRAGMENTS, 2011. GADS)

\begin{tabular}{|c|c|c|c|c|c|c|c|}
\hline \multirow{3}{*}{ 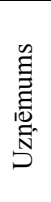 } & \multirow{2}{*}{\multicolumn{2}{|c|}{$\begin{array}{c}\text { Bankrota } \\
\text { varbūtības } \\
\text { novērtējums }\end{array}$}} & \multirow{3}{*}{ 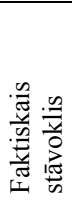 } & \multicolumn{4}{|c|}{ Rezultātu novērtējums } \\
\hline & & & & \multicolumn{2}{|c|}{ 1. modelis } & \multicolumn{2}{|c|}{ 2. modelis } \\
\hline & 1. $\bmod$ & $\begin{array}{c}2 . \\
\text { mod. }\end{array}$ & & $\begin{array}{l}\text { Iegūtais } \\
\text { rezultāts }\end{array}$ & $\begin{array}{l}\text { Atbil } \\
\text { stība }\end{array}$ & $\begin{array}{l}\text { Iegūtais } \\
\text { rezultāts }\end{array}$ & $\begin{array}{l}\text { Atbil } \\
\text { stíba }\end{array}$ \\
\hline 1 & 1,00 & 0,86 & $\mathrm{~N}$ & $\mathrm{~B}$ & 1 & $\mathrm{~N}$ & 1 \\
\hline 2 & 0,29 & 0,92 & $\mathrm{~N}$ & $\mathrm{~N}$ & 1 & $\mathrm{~N}$ & 1 \\
\hline \multirow[t]{2}{*}{3} & 0,00 & 0,91 & $\mathrm{~N}$ & $\mathrm{~N}$ & 0 & $\mathrm{~N}$ & 1 \\
\hline & $\ldots$ & $\ldots$ & $\ldots$ & $\ldots$ & $\ldots$ & $\ldots$ & $\ldots$ \\
\hline 10 & 0,32 & 0,88 & $\mathrm{~N}$ & $\mathrm{~N}$ & 1 & $\mathrm{~N}$ & 1 \\
\hline 11 & 0,02 & 0,89 & $\mathrm{~N}$ & $\mathrm{~N}$ & 1 & AMP & 0 \\
\hline \multirow[t]{2}{*}{12} & 1,00 & 1,54 & B & $\mathrm{B}$ & 1 & AMP & 1 \\
\hline & $\ldots$ & $\ldots$ & $\ldots$ & $\ldots$ & $\ldots$ & $\ldots$ & $\ldots$ \\
\hline 18 & 0,76 & 0,82 & $\mathrm{~N}$ & $\mathrm{~B}$ & 1 & $\mathrm{~N}$ & 1 \\
\hline 19 & 0,00 & 0,75 & $\mathrm{~N}$ & $\mathrm{~N}$ & 0 & AMP & 0 \\
\hline \multirow[t]{2}{*}{20} & 0,96 & 3,49 & $\mathrm{~N}$ & $\mathrm{~B}$ & 1 & $\mathrm{~N}$ & 1 \\
\hline & $\ldots$ & $\ldots$ & $\ldots$ & $\ldots$ & $\ldots$ & $\ldots$ & $\ldots$ \\
\hline 27 & 0,74 & 0,96 & $\mathrm{~N}$ & B & 0 & $\mathrm{~N}$ & 1 \\
\hline 28 & 0,59 & 0,99 & $\mathrm{~N}$ & B & 0 & $\mathrm{ABP}$ & 0 \\
\hline 35 & 0,41 & 0,75 & $\mathrm{~N}$ & $\mathrm{~N}$ & 1 & $\mathrm{ABP}$ & 0 \\
\hline \multirow[t]{2}{*}{36} & 0,5 & 1,81 & $\mathrm{~N}$ & $\mathrm{~N}$ & 0 & $\mathrm{~N}$ & 1 \\
\hline & $\ldots$ & $\ldots$ & $\ldots$ & $\ldots$ & $\ldots$ & $\ldots$ & $\ldots$ \\
\hline 39 & 0,00 & 0,81 & $\mathrm{~N}$ & $\mathrm{~N}$ & 1 & $\mathrm{~N}$ & 1 \\
\hline 40 & 0,00 & 0,77 & & $\mathrm{~N}$ & 1 & $\mathrm{~N}$ & 1 \\
\hline \multirow{2}{*}{\multicolumn{3}{|c|}{$\begin{array}{l}\text { Pareizi identificēto } \\
\text { uzñēmumu skaits }\end{array}$}} & & Kopā & 21 & \multicolumn{2}{|c|}{32} \\
\hline & & & & $\%$ & 53 & \multicolumn{2}{|c|}{80} \\
\hline
\end{tabular}

analizējamo uzṇēmumu atrodas liela bankrota riska zonā (53\%). Tas nozīmē, ka iegūtie rezultāti atbilst augstas maksātnespējas varbūtības stāvolim, kaut gan pēc Latvijas Uzñēmumu reǵistra faktiskajām ziņām 2010.gadā visi uzñēmumi bija maksātspējīgi, bet 2011.gadā (sk. 2.att.) par maksātnespējīgu atzīts tikai viens uzñēmums.

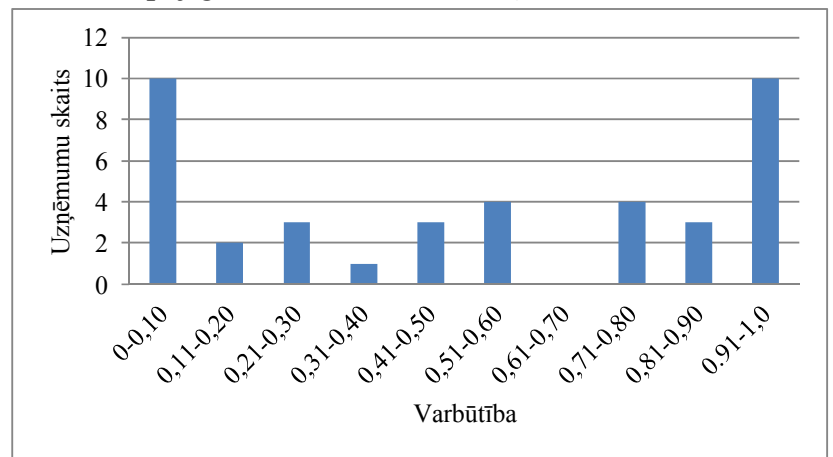

2.att. Uzņēmumu bankrota varbūtības sadalījums 2011.gadā (rezultātu novērtējuma pēc M.Zmijevska metodes).
Bankrota varbūtības novērtējuma rezultāti pēc Genrihas, Petteres un Voronovas model̦a, kuri par analizējamo periodu atbilst 10 uzñēmumu reitinga klasēm, atspoguloti 3.att. Ir maz ticams, ka uzñēmumi, kuri atbilst 1.-5. reitinga klasei ar zemu bankrota varbūtību (PD) no 0.01 līdz 1.25\%, tuvākā gada laikā bankrotēs. Savukārt 6.-9. klases uzn̦ēmumi ( $P D$ no 1,25 līdz $8 \%$ ) ir ar augstu maksātnespējas pakāpi, bet 10. klases uzņēmumi ( $P D$ no $8 \%$ līdz $15 \%$ ) ir praktiski maksātnespējīgi.

Pēc šñ model̦a datiem bankrota varbūtības novērtēšanas rezultāti izskatās reālistiskāki $-65 \%$ no apsekotajiem uzñēmumiem ir zema bankrota varbūtība un nevienam nav pasludināta maksātnespēja. Tāpat šis modelis pareizi novērtēja vien̄̄go oficiāli bankrotējošo uzṇēmumu (12. kods).

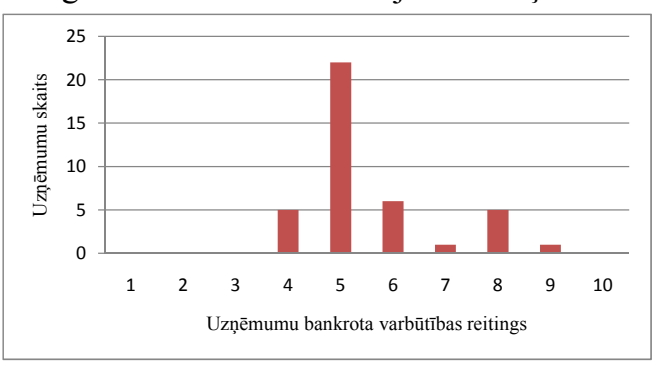

3.att. Uzñēmumu bankrota varbūtības sadalījums 2011.gadā (rezultātu novērtējuma pēc Genrihas, Petteres un Voronovas metodes).

Pēc autoru domām, ņemot vērā faktu, ka izlases kopa nesaturēja pietiekamu skaitu uzņēmumu, kuru faktiskais statuss būtu vērtējams kā ' 'bankrotējis/maksātnespējīgs'" un līdz ar to nebija iespējams novērtēt otrā līmeņa kḷūdas (uzñēmums faktiski bankrotējis, bet modelis prognozē maksātspēju), iesāktie pētījumi ir jāturpina ar lielāku uzñēmumu skaitu.

\section{IV.SECINĀJUMI}

1.Vispārīgā mērķa finanšu pārskati tiek sagatavoti, balstoties uz pieņēmumu par uzņēmuma darbības turpināšanu, ja vien vadībai nav nolūka vai citas izejas, kā uzņēmumu likvidēt vai pārtraukt tā saimniecisko darbību. Starptautiskajos Grāmatvedības standartos vadībai ir noteikts pienākums izvērtēt uzṇēmuma spēju turpināt darbību un sniegt attiecīgu novērtējumu.

2.Revidenta pienākums ir iegūt pietiekamus un atbilstīgus revīzijas pierādījumus, kas apliecina vadības pieņēmuma par uzñēmuma spēju turpināt darbību atbilstību, kurš izmantots, sagatavojot finanšu pārskatus.

3. Nosakot finanšu pārskatos iekḷauto skaidrojumu atbilstību, revidentam jāizvērtē, vai informācija skaidri pievērš lietotāja uzmanību iespējai, ka uzñēmums, veicot ikdienas saimniecisko darbību, var nebūt spējīgs realizēt savus aktīvus un pildīt saistības. Autori uzskata, ka izvērtēšanas procesā būtu lietderīgi izmantot arī dažādus maksātnespējas prognozēšanas model̦us. 
4. Bankrota varbūtības novērtējuma precizitāte pēc Zmijevska modela bija 55\% (2010.gads) un 53.5 (2011.gads). Genrihas, Petteres, Voronovas modeḷa precizitāte, prognozējot bankrota stāvokli - 65\% (2010.gadā) un 80\% (2011.gadā). Autori uzskata, ka iepriekšminēto model̦u pielietošana kompleksai hipotēzes par darbības nepārtrauktību novērtēšanai ir iespējama.

5. Autoru veiktā testēšana neapstiprināja R.Šneideres pētījumā iegūtos rezultātus par to, ka plaši paz̄stamā M.Zmijevska metodika pietiekami precīzi novērtē Latvijas uzṇēmumu maksātspēju. Salīdzinoši labāki rezultāti tiek iegūti, pielietojot Gehrihas, Petteres un Voronovas metodiku.

\section{LITERATŪRAS SARAKSTS}

[1] Going Concern, ISA 570. 2006. International Federation of accounts [skatīts 05.07.2012.]. Piejams http://www.iasplus.com/en/binary/ifac/ 0703edisa570.pdf.

[2] Green paper. Audit policy: Lessons from the Crisis. [skatîts 05.07.2012.]. Pieejams http://ec.europa.eu/internal_market/consulta tions/docs /2010/ audit/summary response en.p .

[3] Waldron, M. Continued Concern for "Going Concern" Reporting. CFA Institute. 2012. [skatîts 05.07.2012.]. Pieejams: http://blogs.cfainstitute. org/marketintegrity/2012/05/22/continued-concern-for-going-concern-re porting/.

[4] K.R. Al-Adeem, Accounting Theory: A Neglected Topic in academic accounting research. Dissertation, Western Reserve University, 2010. 205 p. [skatīts 05.07.2012.]. Pieejams: http://etd.ohiolink.edu/view.cgi? accnum $=$ case 1256045265

[5] A.R. Belkaoui, Accounting Theory. 5th Edition, 2004. Thomson, p. 210 -230 .

[6] R. K. Storey, Revenue Realization, Going Concern and Measurement Of Income. Accounting Review, 1959. vol. 34, N 2, p. 232-238.

[7] W. Hahn, The Going-Concern Assumption: Its Journey into GAAP Accounting \& Audits, 2011, February, p. 26-30. [skatīts 05.07.2012.] Pieejams: http://edit.seu.edu/Editor/assets/seuniversity/academics/facult y/pages.pdf

[8] C. T. Devine, Essay thirteen: Some aspect of scientific method I. Essays in Accounting Theory. Studies in Accounting Research 22. 1985, Vol. II. Sarasota, FL: American Accounting Association. pp.119-130.

[9] J. Betge, Balansovedenie. Moskva: Izd-vo "Buhgalterskij uchet, 2000. 454 c.= Jrg Baetge. Bilanzen. -4 , berarbeitete Auflage. - Dsseldorf: IDW-Verlag GMBH, 1996

[10] J. Graham, D. Kaye A Risk Management Approach to Business Continuity: Aligning Business Continuity with Corporate Governance. Rothsten Associates, 2006. 400 p. ISBN 10:1931332363.

[11] A. Hiles, Business Continuity: Best Practices. Word-Classic Busines Continuity Management. Rothstein Associates Inc., 2003. 290 p. ISBN 13:9781931332224.

[12] Syed, Akhtar, Syed Afsar. Business Continuity Planning Methodology. Sentryx, 2003. 310 p

[13] V.I. Drozzhinov, Moiseenko, G.E. Nepreryvnost biznesa i problemy 2000 goda. Moskva, MCNiTI, 1999. $86 \mathrm{~s}$

[14] L.J. Abbott, Parker, S., Peters, G.F. The effects of post-bankruptcy financing on going concern reporting. Advances in Accounting, 2003 vol. 20, p. 1-22. http://dx.doi.org/10.1016/S0882-6110(03)20001-8

[15] M.A. Geiger, D.V. Rama, Audit Firm Size and Going-Concern Reporting Accuracy. Accounting Horizons, March 2006, vol. 20, N 1. p. 1-17. http://dx.doi.org/10.2308/acch.2006.20.1.1

[16] S.E. Kaplan, D.D. Williams, Do going concern audit reports protect auditors from litigation? A simultaneous equations approach. May 2011. 52 p. [skatīts 07.07.2012.] Pieejams: http://www.isarhq.org/papers/C23_Kaplan_Williams_ISAR_2011.pdf.

[17] A. Vanstraelen, Going-Concern Opinions, Auditor Switching and the Self-fulfilling Prophecy Effect Examined in the Regulatory Context of Belgium. Journal of accounting, auditing \&finance, 2003, vol. 18, N 2, p.231 -253.

[18] D. Foroghi, Shahhahani, A.M. Audit Firm Size and Going-Concern Reporting. Interdisciplinary Journal of Contemporary Research in Business, 2012, vol. 18, No 2, p. 1093 - 1098.
[19] J. Berkson, Application of the Logistic Function to Bio-assay. Journal of the American Association, 1944, N 9, p. 357-365.

[20] J. Ohlson, Financial Ratios and the Probabilistic Prediction of Bankruptcy. Journal of Accounting Research, 1980, N 19, p. 109-131. http://dx.doi.org/10.2307/2490395

[21] M.E. Zmijewski, Methodological Issues Related to the Estimation of Financial Distress Prediction of Financial Distress Prediction Models. Journal of Accounting Research, 1984, vol. 22. Studies on Current Econometric Issues in Accounting Research, p. 59- 82.

[22] W. Hopwood, J.C. McKeown, J.F. Mutchelr, A re-examination of auditor versus model accuracy within context of going-concern decision. Contemporary Accounting Research, vol. 10, N 2 (Springer), p. 409431

[23] M. Khoshtinat, M. Ghasoori, Comparing the financial ratio and accrual ratio for predicting bankruptcy (Text in Persian). The Iranian Accounting Studies (9). 2005. 43-61 p.

[24] E. Altman, Financial Ratios, Discriminant Analysis and the Prediction of Corporate Bankruptcy. Journal of Finance. 1968, N 23, p. 589-609. http://dx.doi.org/10.1111/j.1540-6261.1968.tb00843.x

[25] M. Zmijewski, Methodological Issues Related to the Estimation of Financial Distress Prediction Models. Journal of Accounting Research, 1984, vol. 22, p. 59 - 82. http://dx.doi.org/10.2307/2490859

[26] J. K. Reynolds, J. R. Francis, Does size matter? The influence of large clients on office-level auditor reporting decisions. Journal of Accounting \& Economics, 2000, $30 \quad$ (3), p. $\quad 375-\quad 400$. http://dx.doi.org/10.1016/S0165-4101(01)00010-6

[27] X. Belloty, J-J. Uang, D. Citron, R. Taffler, The predictive Ability of Audit Report Going-Concern Uncertainty Narratives.

[28] J.A. Lawrence, S. Parker, G. F. Peters, The Effects of Post-Bankruptcy Financing on Going Concern Reporting. Advances in Accounting, 2003, vol. 20, p. 1-20. http://dx.doi.org/10.1016/S0882-6110(03)20001-8

[29] M.A. Geiger, D.V. Rama, Audit Firm Size and Going-Concern Reporting Accuracy. Accounting Horizons, 2006, vol. 20, N 1, p. 1 -17. http://dx.doi.org/10.2308/acch.2006.20.1.1

[30] L. Jiang, R. Radich, S. Zhao, The Successful Resolution of Auditor Going Concern Opinions: Evidence from the U.S. and Australia. AFAANZ conference, 2010. [skatīts 13.07.2012.] Pieejams: http: //www.afaanz.org/openconf $/ 2010 /$ modules/request.php?module $=$ oc_pro gram\&action=view.php\&id=225.

[31] S.E. Kaplan, D.D. Williams, Do going concern audit reports protect auditors from litigation? A simultaneous equations approach. [skatīts 13.07.2012.] Pieejams: http://www.uic.edu/classes/actg/actg593/Readin gs/Auditing/Audit-Firm-Size-And-Going-Concern-2pp.pdf

[32] M.L. DeFond, J.R. Francis, X. Hu, The Geography of Auditor Independence and SEC Enforcement. 2008. [skatīts 13.07.2012.] Pieejams: http://www.accountancy.smu.edu.sg/research/seminar/pdf $/ 3 \_0$ defond francis hu may 132008 final.pdf.

[33] P.C. Trønnes, E. Carson, R. Simnett International Consistency in Audit Reporting Behaviour: Evidence from Going Concern Modifications. NCAAR Conference, ANU, December 2008. [skatīts 13.07.2012.] Pieejams: http://www.fdewb.unimaas.nl/ISAR2009/01_03_Tronnes_ Carson Simnett.pdf.

[34] N. Ratzinger, Auditors' Discretionary Scope of Action - German Evidence from Audit and Non-audit Fees and Going Concern Emphasis of Matter Paragraphs. $6{ }^{\text {th }}$ EARNet Symposium, Norway, 2011. [skatīts 13.07.2012.] Pieejams: http://conference.rente.nhh.no/earnet/2011/paper s/Paper 18.pdf.

[35] N. Sormunen, K.K. Jeppesen, S. Sungren, T. Svanströn, Auditors' Going Concern Reporting before Bankruptcy - A Study of Bankrupt Companies in Finland, Sweden, Norway and Denmark. 6 th EARNet Symposium, Norway, 2011. [skatīts 13.07.2012.] Pieejams: http://conference.rente.nhh.no/earnet/2011/papers/Paper 72.pdf.

[36] I.G. Basioudis, M.A. Geiger, V. Papanastasiou, Audit Fees, Non-audit Fees, and Auditor Reporting on UK Stressed Companies. [skatīts 13.07.2012.] Pieejams: http://static.aston.ac.uk/asig/Basioudis.pdf.

[37] A. Vanstraelen, Going-concern opinions, auditor switching, and the selffulfilling prophecy effect examined in the regulatory context of Belgium. Journal of Accounting, Auditing and Finance, 18, 2003. p. 231-253.

[38] N. N. Ovchinnikova, Razvitie metodiki ocenki nepreryvnosti dejatelnosti organizacii. Ekonomicheskie nauki, No 8 (33), 229 $233 \mathrm{~s}$.

[39] N.A. Remizov, Nepreryvnost dejatelnosti i audit // Finansovye i buhgalterskie konsultacii. 2004. №3. C. 55-63 
[40] N. N. Ovchinnikova, Analiticheskie procedury v ocenke nepreryvnosti dejatelnosti organizacii. Avtoreferat dissertacii. Novosibirsk: SibUPK, 2011. $16 \mathrm{~s}$.

[41] Primenimost dopuschenija nepreryvnosti dejatelnosti audiruemogo lica. Pravilo (Standart) auditorskoj dejatelnosti (PSAD) N 11. [skatīts 07.07.2012.] Pieejams: http://www.rosec.ru laudit/standard/standard6.html

[42] N.V. Shalanov, Sistemnyj analiz. Kibernetika. Sinergetika: matematicheskie metody i modeli. Ekonomicheskie aspekty. Novosibirsk, NGTU, 2008. $288 \mathrm{c}$.

[43] S. Lili, The effects of client's size and stress criteria on bankruptcy prediction models: an empirical analysis. [skatīts 23.07.2012.] Pieejams: http:// saahq.org/audit/midyear/04midyear/papes/bpt-stres\%20 size.doc.

[44] A. Young, Y. Wang, Multi-risk level examination of going concern modification. Managerial Auditing Journal, vol. 25, iss. 8, p.756 - 791 . http://www.emeraldinsight.com/journals.htm?articleid $=1881518$

[45] R. Šorins, I. Voronova, Uzñēmuma maksātnespējas novērtējums. // Ekonomiskās problēmas uzṇēmējdarbīibā. Rīga : RTU, 1998. 125.-131. lpp.

[46] I. Voronova, J. Romancēviča, Uzṇēmumu ekonomiskās stabilitātes noverrtēšana. 6 International Scientific Conference. Public Relations: Quality, Benefits and Risks, Selected papers, Riga, Biznesa augstskola TURĪBA, 2005. p. 134-142.

[47] R. Šneidere, Finanšu analīzes metodes uzṇēmuma maksātnespējas prognozēěanai. Rīga, Lietišķās informācijas dienests, 2009.- 232 lpp.

[48] Škiltere, D., Žuka, R. Statistical Evaluation of Applying of Forecasting an Enterprise's Financial Condition in Latvia. Scientific Papers University of Latvia. vol. 706, Riga, LU, 2006. p. 109 - 124.

[49] I. Genriha, I. Voronova, Maksātnespējas noteikšanas modeḷi Latvijas uzņēmumiem // RTU zinātniskie raksti. 3. sēr., Ekonomika un uzn̄ēmējdarbība. 8. sēj., 2010. 38.-50. lpp

[50] K. Didenko, J. Mežiels, I. Voronova, Assessment of Enterprises Insolvency: Challenges and Opportunities // 17th International Scientific Conference "Economics and Management-2012" (ICEM-2012), Estonia, Tallinn, 28.-30. March, 2012. p. 69-76.p.
[51] I. Voronova, Financial Risks: Cases of Non-Financial Enterprises. In Risk Management for the Future - Theory and Cases. InTech, 2012. p.435-466.

[52] Z. Muceniece, N. Lāce, Tirdzniecības uznēmumu maksātnespējas prognozēšana Latvijā // Ekonomiskie pētījumi uzṇēmējdarbībā. - 8. sējums, 2010. 141.-149. 1pp.

[53] I. Genriha, I. Voronova, Maksātnespējas noteikšanas modeli Latvijas uzṇēmumiem. // RTU IEVF Zinātniskie raksti. Ekonomiskie pētījumi uzñēmējdarbībā. 8. sējums. - Rīga: RTU Izdevniecība, 2010.

[54] I. Genriha, G. Pettere, I. Voronova, Entrepreneurship Insolvency Risk Management: case Latvia.//International Journal of Banking, Accounting and Finance (IJ BAAF), 2011, vol. 3. N 1. [skatīts 13.07. ]

Janis Meziels is Professor of Investment and Financial Management at Faculty of Engineering Economics and Management of Riga Technical University. He has master's degree in Management of Entrepreneurship and twenty- nine years of teaching practice in entrepreneurship and finance.

Certified auditor by the Association of Certified Auditors of Latvia since 2000.

E-mail: janis.meziels@rtu.lv

Irina Voronova is Associated Professor of Investment and Financial Management at Faculty of Engineering Economics and Management of Riga Technical University. She holds a Doctor Degree in Economy of Latvian Academy of Sciences. She has thirty-five years of teaching practice in entrepreneurship and finance. Her academic publications include articles in the Journal of Business economics and Management (Vilnius), Scientific Proceedings of Riga Technical University, International Congress of Actuaries and others. She is the co-author of the first textbook of Risk Management in Latvian language. She is member of Boarder of Latvian Actuarial Association

E-mail: irina.voronova@rtu.lv

\section{Janis Mežiels, Irina Voronova. The Audit of Going Concern Assumption and Risk Assessment.}

The article is devoted to the study of the existing practice of the assessment of going concern in compliance with international audit standards. The authors conduct the analysis of the factors of binominal models of audit conclusions about a going concern, methodological approaches of integral assessment and conformity of risk classes to the kinds of audit conclusions about a going concern. The analysis of binomial models demonstrated that a number of factors incorporated into the model range from 5 to 19. Factors can be combined into 3 groups - financial, corporate management and other factors, characterising an auditing company. Financial ratios group includes the results of the assessment of enterprise bankruptcy, executed by using established models (Zmijewski, Hopwood). The authors on the basis of bibliometric analysis stated that detection of going concern risk as a rule is considered by the auditor as a homogeneous risk class. And it is irrespective of the fact that auditors have the right to introduce different excuses related to a going concern. There is an attempt (Young\&Wang) to offer the interdependence of risk classes (determined on the basis of Altman model) and types of audit conclusions. The authors suggested using the method of hierarchy analysis for getting an integral assessment of following going concern opinion. One of the main indicators belonging to the group of financial indicators of the assessment of going concern is an indicator of the insolvency/bankruptcy assessment. The authors research the possibility of using bankrupt forecast model relating to the models of probability for Latvian enterprises. The authors assessed the precision of two models on the example of the selection of the small and medium sized enterprises of Latvia. The results of research demonstrated that logit model by Genriha, Petera and Voronova produces high level of precision of the assessment of bankruptcy probability and can be used in the assessment of following the going concern principle.

\section{Янис Межиельс, Ирина Воронова. Аудит принципа непрерывности деятельности и оценка рисков.}

Исследование посвящено изучению существующей практике оценки непрерывности деятельности в соответствии с международными аудиторскими стандартами. Проводится анализ факторов биноминальных моделей аудиторских заключений о непрерывности деятельности, методологических подходов интегральной оценки и соответствия классов риска видам аудиторских заключений о непрерывности деятельности. Анализ биноминальных моделей показал, что количество факторов входящих в модель колеблется от 5 до 19. Факторы можно сгруппировать в три группы - финансовые, корпоративного управления и другие факторы, характеризующие аудитирующую компанию. В группу финансовых коэффициентов включаются результаты оценки банкротства предприятия, выполненные с использованием известных моделей (Змиевского, Хопвуда). Авторы на основе на библиметрического анализа констатировали, что раскрытие риска непрерывностью деятельности, как правило, рассматривается аудитором как однородный класс риска. И это несмотря на то, что аудиторы имеют право давать различные оговорки в отношении непрерывности деятельности. Имеется попытка (Young\&Wang) предложить зависимость классов риска (определенных на основе модели Альтмана) и видов аудиторских заключений. Авторы предложили использовать метод анализа иерархий при получении интегральной оценки соблюдения принципа непрерывности. Одним из важных показателей входящих в группу финансовых показателей оценки непрерывности деятельности является показатель оценки неплатежеспособности/банкротства. Авторы исследуют возможность использования моделей прогнозирования банкротства относящихся к моделям условной вероятности для Латвийских предприятий. Авторы выполнили оценку точности двух моделей (Змиевский, Генриха) на примере выборки малых и средних предприятий Латвии. Результаты исследования показали, что логит модель Генрихи, Петтеры и Вороновой дает высокую точность оценки вероятности банкротства и может быть использована при оценке соблюдения принципа непрерывности деятельности. 